\title{
David Oliver: Binary truths don't help health policy debate
}

\section{David Oliver consultant in geriatrics and acute general medicine}

Berkshire

Stephen Hawking and Jeremy Hunt's public argument in August over the future of the NHS and use of data led to some hard hitting claims and strong accusations on both sides. ${ }^{12}$ In the aftermath of the spat the management consultant Stephen Black wrote a provocative piece on the current state of debate about the NHS. ${ }^{3}$ Black's thesis was that we can't move forward with constructive solutions to the problems facing our health and care system if the debate is reduced to falsely polarised, oversimplified arguments that are based on ideology rather than on pragmatism.

I don't always agree with Black's managerialist approach and have clashed with him before, ${ }^{4}$ but his argument deserves consideration. If we are sincere about protecting and sustaining services, we should sometimes focus on pragmatic solutions that deliver improvement, whether or not they accord with our political ideology.

For instance, England's sustainability and transformation partnerships (STPs) ${ }^{5}$ could in theory deliver win-win benefits by giving more control and autonomy to local clinical teams to improve care and also more permission for organisations to collaborate in the interests of a population. They have been rightly criticised for being rushed, for overpromising savings, and for lacking clinical engagement. ${ }^{67}$ It is not helpful to discuss such localism only in terms of covert privatisation, dismantling of the NHS, and central government's abdication of accountability. Countries such as Scotland and Sweden plan change for populations of similar sizes to those in STPs.

On Black's point about false dichotomies, I would say that in many areas of health policy two apparently contradictory views can each be partly true. The two views may be valid and perfectly reconcilable if we are prepared to consider both viewpoints when deciding how to proceed.

The NHS is facing a major funding gap long warned of by expert health economists that is harming service delivery. ${ }^{8}$ It needs cash. But there are further possible efficiencies from tackling unwarranted variation, fragmentation, and unproductive or unevidenced areas of spending. And, as with every system, we do need to discuss long term, sustainable solutions to funding and delivery. ${ }^{9}$

We do have a major problem with workforce planning, retention, and recruitment. Yet, as Black argued, we could do far more to support, value, and retain the existing workforce, and much of this sits with local service leaders; we can't only blame the government and its arm's length bodies.

We do have among the fewest hospital beds, and highest occupancy rates, ${ }^{10}$ per head of population in the OECD, with acute admissions and delayed transfers still rising. Yet many people in hospital beds could be supported outside hospital, and we could do more in hospital processes to improve patient flow, get more patients home sooner, and use scarce beds wisely.

Finally, the NHS is widely acknowledged as delivering high levels of efficiency and equity in a service that is free at the point of delivery. ${ }^{11}$ But health systems in some other countries also deliver universal public health services, with equal or better outcomes, sometimes at similar expenditure levels or with the ability to spend more per capita on health.

We should not let the fear of being shouted down stop us exploring and learning from other health systems

I don't subscribe to the dogma trotted out by right wing think tanks that such health systems are inherently superior and show that the NHS model is broken. But, equally, we should not let the fear of being shouted down stop us exploring and learning from other health systems as we debate the NHS's future.

Competing interests: See www.bmj.com/about-bmj/freelancecontributors/david-oliver.

Provenance and peer review: Commissioned; not externally peer reviewed.

Follow David on Twitter: @mancunianmedic

Clarke R. The professor and the politician. BMJ 2017;359:j3972. doi:10.1136/bm j3972 pmid:28838959.

Rimmer A. Debating the future of the NHS: Hawking versus Hunt. BMJ 2017;359:j4007. doi:10.1136/bmj.j4007 pmid:28838929. 
3 Black S. We can't improve the NHS if we conduct all debate about it using shibboleths not analysis. Linkedln. Sep 2017. https://www.linkedin.com/pulse/we-cant-improve-nhsconduct-all-debate-using-analysis-stephen-black.

4 Electronic responses. Stop wasting taxpayers' money on management consultancy for the NHS. BMJ 2014. www.bmj.com/content/349/bmj.g7243/rapid-responses.

5 King's Fund. Sustainability and transformation plans (STPs) explained. 2017. https://www. kingsfund.org.uk/topics/integrated-care/sustainability-transformation-plans-explained.

6 Royal College of Physicians. Background to sustainability and transformation plans (STPS) 2016. https://www.rcplondon.ac.uk/projects/outputs/background-sustainability-andtransformation-plans-stps.

7 King's Fund. Sustainability and transformation plans in London: an independent analysis of the October 2016 STPs (completed in March 2017). 2017. https://www.kingsfund.org. uk/publications/sustainability-and-transformation-plans-london.
8 Appleby J, Gainsbury S. NHS funding choices and the 2017 general election. Nuffield Trust. 2017. https://www.nuffieldtrust.org.uk/research/nhs-funding-choices-and-the-2017general-election.

9 Crisp N. What would a sustainable health and care system look like? BMJ 2017;359:j3895. doi:10.1136/bmj.j3895 pmid:28870886.

10 Richardson J. What's really happening with hospital bed numbers? BMJ 2017;359:j4439 doi:10.1136/bmj.j4439 pmid:28954730.

11 NHS Confederation. UK NHS named best healthcare system by the Commonwealth Fund. 2014. www.nhsconfed.org/resources/2014/07/uk-nhs-named-best-healthcare-system-bythe-commonwealth-fund.

Published by the BMJ Publishing Group Limited. For permission to use (where not already granted under a licence) please go to http://group.bmj.com/group/rights-licensing/ permissions 